\title{
Nicipe rosulata (Ornithogaloideae, Hyacinthaceae), a New Species from the Little Karoo in South Africa, with a New Combination in the Genus
}

\author{
Mario Martínez-Azorín, ${ }^{1,2}$ Manuel B. Crespo, ${ }^{2}$ Anthony P. Dold, ${ }^{3}$ Michael Pinter, ${ }^{1}$ and Wolfgang Wetschnig ${ }^{1}$ \\ ${ }^{1}$ Institute of Plant Science, Karl-Franzens-University Graz, Holteigasse 6, A-8010, Graz, Austria. \\ ${ }^{2}$ CIBIO (Instituto Universitario de la Biodiversidad), Universidad de Alicante, P. O. Box 99, E-03080 Alicante, Spain. \\ ${ }^{3}$ Selmar Schonland Herbarium, Department of Botany, Rhodes University, Grahamstown 6140, South Africa. \\ Author for correspondence (mmartinez@ua.es)
}

\section{Communicating Editor: Marcia Waterway}

\begin{abstract}
A new species of Nicipe from the Little Karoo in South Africa is here described. Nicipe rosulata sp. nov. is characterized by its (3-)5-8 short and broad, somewhat leathery leaves disposed in a basal rosette, its narrowly ovate, acute-apiculate capsules, and its long papillate-echinulate seeds. This species is at first sight related to Nicipe britteniae and Ornithogalum lithopsoides based on their short leaves with ciliate to fimbriate margins, but it differs in floral and vegetative characters that clearly support its recognition as a distinct species. Nicipe britteniae differs from N. rosulata by the hard, distichous, ensiform, conduplicate, and densely fimbriate leaves and the rugose seeds. Ornithogalum lithopsoides clearly differs by the more numerous and much thinner leaves, and the rugose seeds, among other characters. Here we provide a detailed morphological description for Nicipe rosulata, including ecological and chorological data, and discuss relationships with its close allies. Finally, the recently described Ornithogalum lithopsoides, also from the Little Karoo, clearly belongs to Nicipe based on the leathery rosulate leaves all arising nearly at the same level, the relatively small flowers, the tepals with a dark longitudinal band mostly visible on the abaxial side, and the small capsules and seeds. This new combination in the latter genus is also presented here.
\end{abstract}

Keywords—Asparagaceae, Nicipe, Ornithogaleae, Ornithogalum lithopsoides, Scilloideae, taxonomy, Western Cape.

Hyacinthaceae sensu APG II (2003) includes about 1,000 species of bulbous plants that are segregated in four monophyletic subfamilies (Oziroeoideae, Ornithogaloideae, Urgineoideae, and Hyacinthoideae). The family is mainly distributed through Europe, Africa, and southwestern Asia, with a single small genus in South America corresponding to subfamily Oziroëoideae. Alternatively, Hyacinthaceae is treated as subfamily Scilloideae of Asparagaceae, and the subfamilies above are respectively then treated as tribes Oziroëeae, Ornithogaleae, Urgineeae, and Hyacintheae (e.g. APG III 2009; Chase et al. 2009), though we favor the former treatment based on morphological grounds.

The latest comprehensive study in Ornithogaloideae (Martínez-Azorín et al. 2011) demonstrates the existence of 19 monophyletic genera that are characterized by a remarkable syndrome of morphological characters, resulting in genera that are easy to recognize because of their homogeneity in floral and fruit morphology. Among these genera, Nicipe Raf. was described by Rafinesque (1837) to include a single species, Ornithogalum niveum Aiton. It is worth mentioning that the latter taxon is probably the priority name for O. juncifolium Jacq. (cf. Müller-Doblies and MüllerDoblies 1996), but further studies are needed to decide that matter.

Nicipe was overlooked by most modern authors for nearly two centuries until Martínez-Azorín et al. (2011) accepted its autonomy. This genus includes about 45 species mainly occurring in southern Africa, with a single species, N. gracillima (R. E. Fr.) Mart.-Azorín, M. B. Crespo \& Juan, disjunctly occurring in east Africa (Martínez-Azorín et al. 2011). Nicipe is characterized by the leaves usually narrow and long, somewhat leathery, all arising nearly at the same level from the tip of the bulb neck, inflorescence racemose or rarely subcorymbose, bracts aristate, tepals white to yellowish on the adaxial side with a green to brownish longitudinal band mostly visible on the adaxial side, capsules relatively small enclosed by the withered perianth segments, and seeds usually numerous and irregularly compressed (Martínez-Azorín et al. 2011).

From a phylogenetic point of view, Nicipe is sister to the clade comprising most of the Eurasian genera such as Cathissa Salisb., Melomphis Raf., Loncomelos Raf., Honorius Gray, and Ornithogalum L. (Martínez-Azorín et al. 2011), and therefore Nicipe appears to be the evolutionary link between some of the southern African and Eurasian groups.

Our current research is focused on the taxonomic revision of Nicipe. During field work in South Africa between 2005 and 2011, plants belonging to Nicipe with a distinct morphology were found in two locations in the Little Karoo in the Western Cape province of South Africa. These plants show a distinct syndrome of floral and vegetative characters that we describe here as a new species, Nicipe rosulata.

\section{Materials And Methods}

A detailed morphological study of wild living plants of Nicipe rosulata (32 plants from two populations) as well as $N$. britteniae (five plants from one population) and N. lithopsoides (11 plants from one population) was undertaken, as detailed in Martínez-Azorín et al. $(2007,2009)$ (Table 1). These data were complemented with measure- T1 ments taken from cultivated plants and herbarium collections deposited at ABH, GRA, K, and NBG (acronyms according to Thiers 2014). Light microscope observations were carried out using an OLYMPUS SZX12 binocular with objective DFPL-1X-PF and incorporated micrometer, and with adapted digital camera OLYMPUS Altra 20. Images were obtained with software AnalySIS getIT for Windows. Scanning electron microscope (SEM) images of five seeds collected from two plants were taken with an SEM JEOL JSM 840. As the material was dried and resistant, no special treatment was required prior to observation. Samples were directly glued on metallic stubs, and they were afterwards coated with about $30 \mathrm{~nm}$ gold. Authorities of the cited taxa follow IPNI (2014).

\section{TAXonomic TREATMENT}

Nicipe rosulata Mart. -Azorín, M. B. Crespo, A. P. Dold, M. Pinter \& Wetschnig, sp. nov.-HOLOTYPE: SOUTH AFRICA. Western Cape Province. ca. $30 \mathrm{~km}$ west of 
TABLE 1. Plants of Nicipe studied from natural populations in South Africa.

\begin{tabular}{|c|c|c|c|}
\hline & Locality & Number of plants studied & Herbarium voucher \\
\hline \multirow[t]{2}{*}{ N. rosulata } & Western Cape, ca. 30 km W of Oudtshoorn & 24 & M. Martínez-Azorín et al. MMA899 (GRA, ABH, K) \\
\hline & $\begin{array}{l}\text { Western Cape, ca. } 11 \mathrm{~km} \text { SW of Calitzdorp, Gamkaberg } \\
\text { Nature Reserve }\end{array}$ & 8 & M. Martínez-Azorín et al. MMA941 (GRA, ABH) \\
\hline N. britteniae & Eastern Cape, Table Hill Farm, N of Grahamstown & 5 & A. P. Dold 4458 (GRA) \\
\hline N. lithopsoides & Western Cape, Grootkop Nature Reserve, N of Oudtshoorn & 11 & M. Martínez-Azorín et al. MMA894 (ABH, GRA) \\
\hline
\end{tabular}

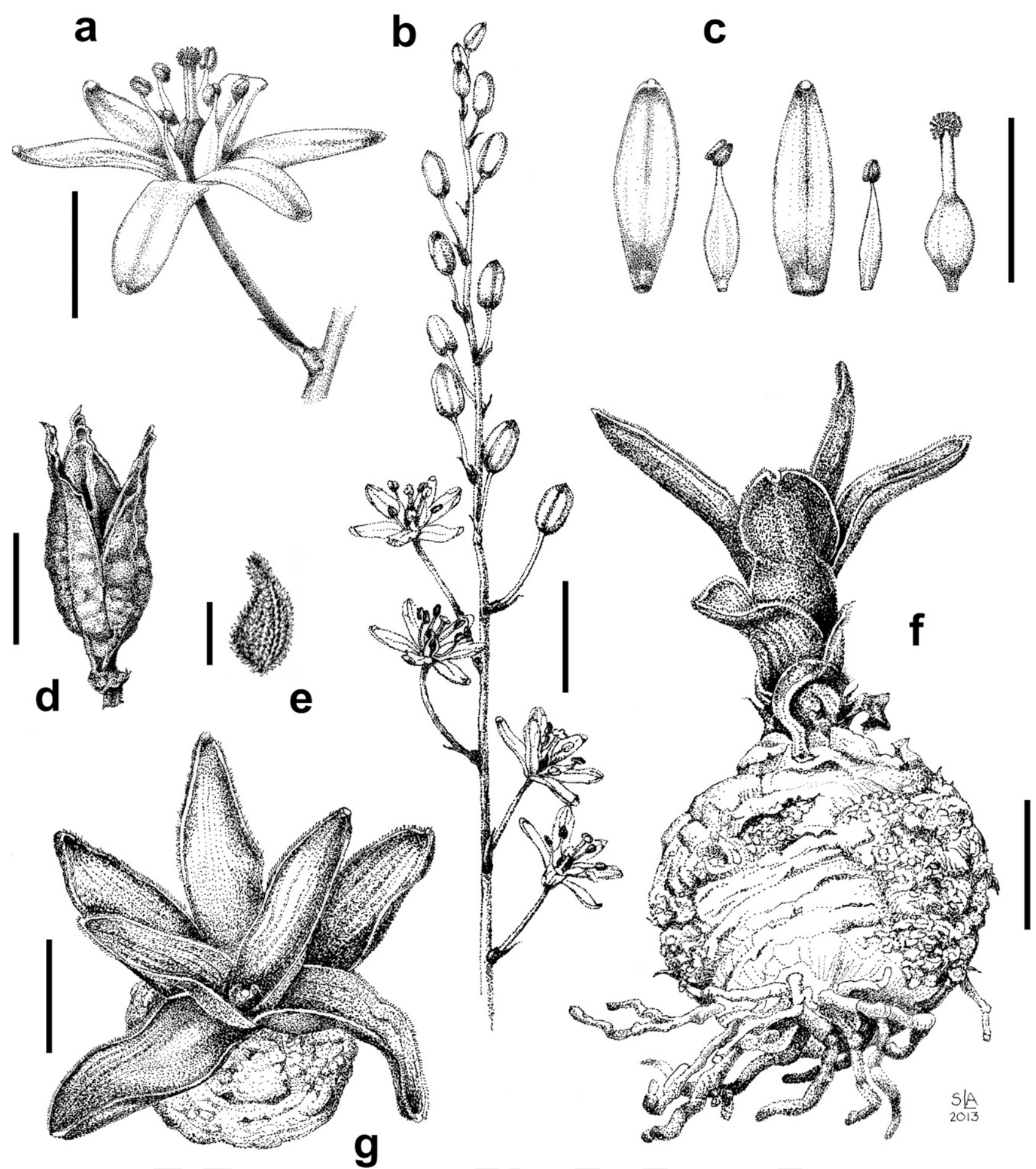

FIG. 1. Nicipe rosulata Mart.-Azorín et al. a. Flower, pedicel and bract. b. Inflorescence. c. Dissected flower; left: inner tepal and stamen; right: outer tepal and stamen and gynoecium. d. Dehiscing capsule. e. Seed. f. Bulb with leaves, lateral view. g. Bulb with leaves, apical view. Scales a, c: 5 mm; b, g, f: $1 \mathrm{~cm}$; d: $2 \mathrm{~mm}$; e: $0.5 \mathrm{~mm}$. 
Oudtshoorn, on 'cement road' to Calitzdorp, sandy soil in stony veld, $223 \mathrm{~m}$, 28/09/2011, M. Martínez-Azorín, A. P. Dold, J. Vlok \& A. Martínez-Soler MMA899 (holotype: GRA; isotypes: $\mathrm{ABH}, \mathrm{K})$.

Planta ob folia breviora latioraque ad $N$. britteniae et O. lithopsoidem accedens, sed eis facile distinguitur foliis planis et canaliculatis in rosulis congestis dispositis et seminibus longe papilloso-echinulatis. A priore insuper tamen differt foliis spiraliter (non distiche) dispositis, subcoriaceis, ad margines breviter fimbriatis (in illa fimbriis $0.8 \mathrm{~mm}$ longis). A posteriore insuper discrepat foliis synanthiis, minus numerosis (3-8), multo latioribus et minus coriaceis, ad margines longe fimbriatis (in illa ciliolatis, ciliis usque ad $0.2 \mathrm{~mm}$ longis).

Bulbous plants up to $20 \mathrm{~cm}$ tall. Bulb mostly epigeal, not proliferous, ovoid to spherical or slightly depressed, $1.5-3 \times 2-3 \mathrm{~cm}$, with pale brown to greyish membranous outer tunics, ending into a $0.3-1 \mathrm{~cm}$ long epigeal neck. Roots fleshy, narrow, white, branched, up to $30 \times 1.5 \mathrm{~mm}$. Leaves (3-)5-8, spirally arranged in a basal rosette, suberect or slightly spreading, ovate-oblong, canaliculate with subcucullate apex, somewhat leathery, sheathing the stem at the base, $1.5-4(-7) \times 0.4-0.8(-1) \mathrm{cm}$, green, glabrous with long and densely ciliate margins, with cilia $0.3-0.5 \mathrm{~mm}$ long. Inflorescence an erect raceme, 5-10 cm

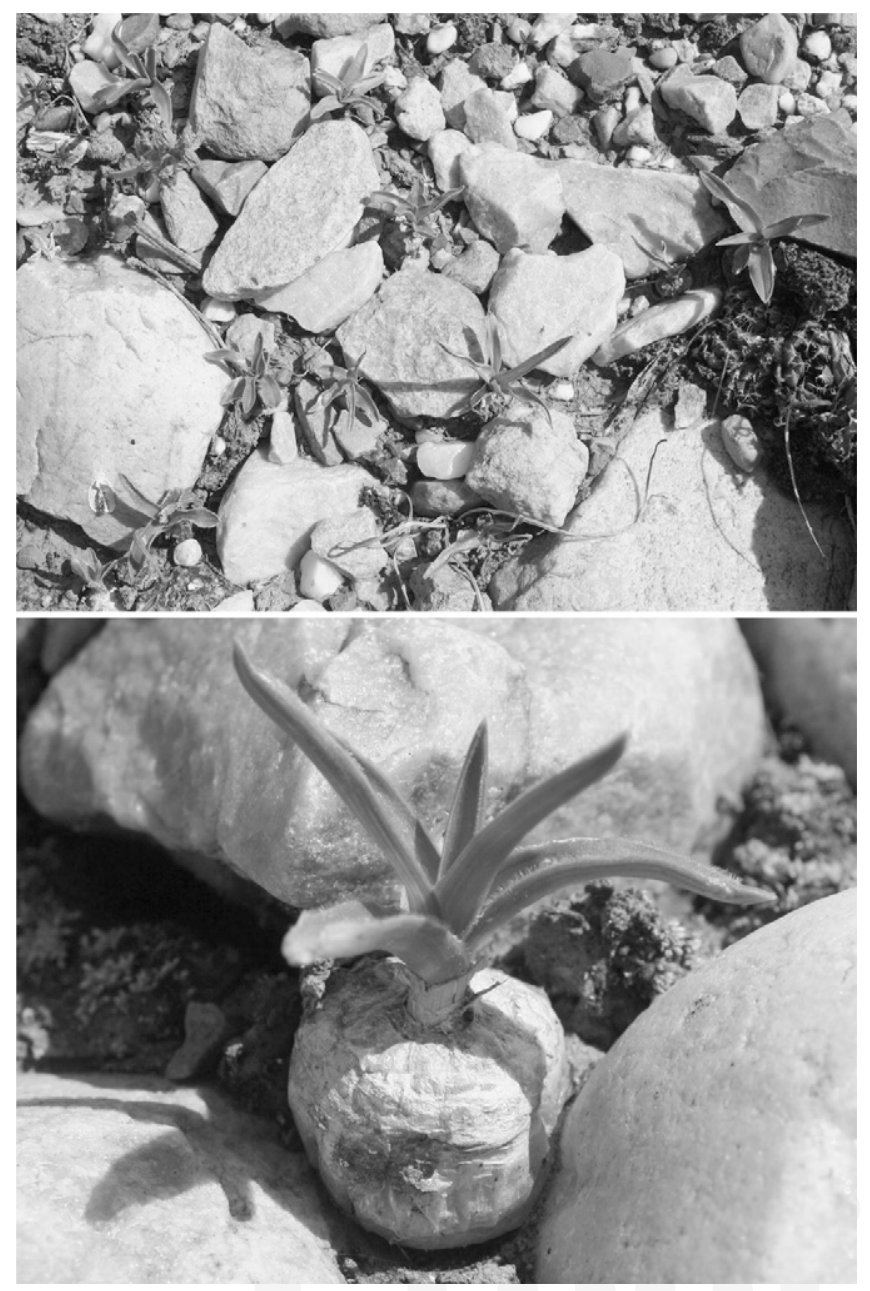

FIG. 2. Nicipe rosulata in habitat at the type locality. long excluding the peduncle with 7-25 flowers; peduncle 8-10 cm long, erect; flower pedicels 5-10 mm long, patent to erect-patent, suberect and slightly longer in fruit; bracts ovate-lanceolate, long acuminate, auriculate, ca. $1.5-2 \mathrm{~mm}$ long, much shorter than pedicels at anthesis, membranous, white with a central green to brownish midrib. Flowers patent to suberect; tepals white with a green longitudinal stripe ca. $0.5 \mathrm{~mm}$ wide and visible mostly on the abaxial side; outer tepals narrowly-lanceolate, 5.5-7 × 1.8-2.2 mm; inner tepals lanceolate, 5-6.5 × 1.5-2 mm. Stamens dimorphic; outer filaments narrowly linear, 3-3.5 $\times 0.5 \mathrm{~mm}$, inner ones ovate-lanceolate, much wider at the base, 3.5-4.2 × 1-1.3 mm; anthers all similar, 0.7-0.8 mm long. Ovary ovate, green at the upper half and white in the lower half, $2 \times 1.5 \mathrm{~mm}$, slightly stipitate; style narrow, white, erect, 2-2.5 $\times 0.5 \mathrm{~mm}$; stigma trigonous-subcapitate, covered by numerous papillae. Capsule narrowly ovatelanceolate, acute, apiculate, 4-5.5 × 1.5-2 mm, on a short stipe up to $0.5 \mathrm{~mm}$ long. Seeds irregularly compressed, 0.4-1 × 0.3-0.5 mm, angulate, sometimes apiculate, black, long papillate-echinulate. Figures 1-3, Table 2.

Etymology-It is named after the broad and short leaves disposed in a spirally arranged basal rosette (rosulatus, $-\mathrm{a}$, - um $=$ forming or disposed in a rosette).

Phenology-In cultivation the species flowers in the late summer (July-September when cultivated in the Northern Hemisphere in Alicante, and February in the Southern Hemisphere, Grahamstown). Capsules appear in September in Alicante and dehisce in late September.
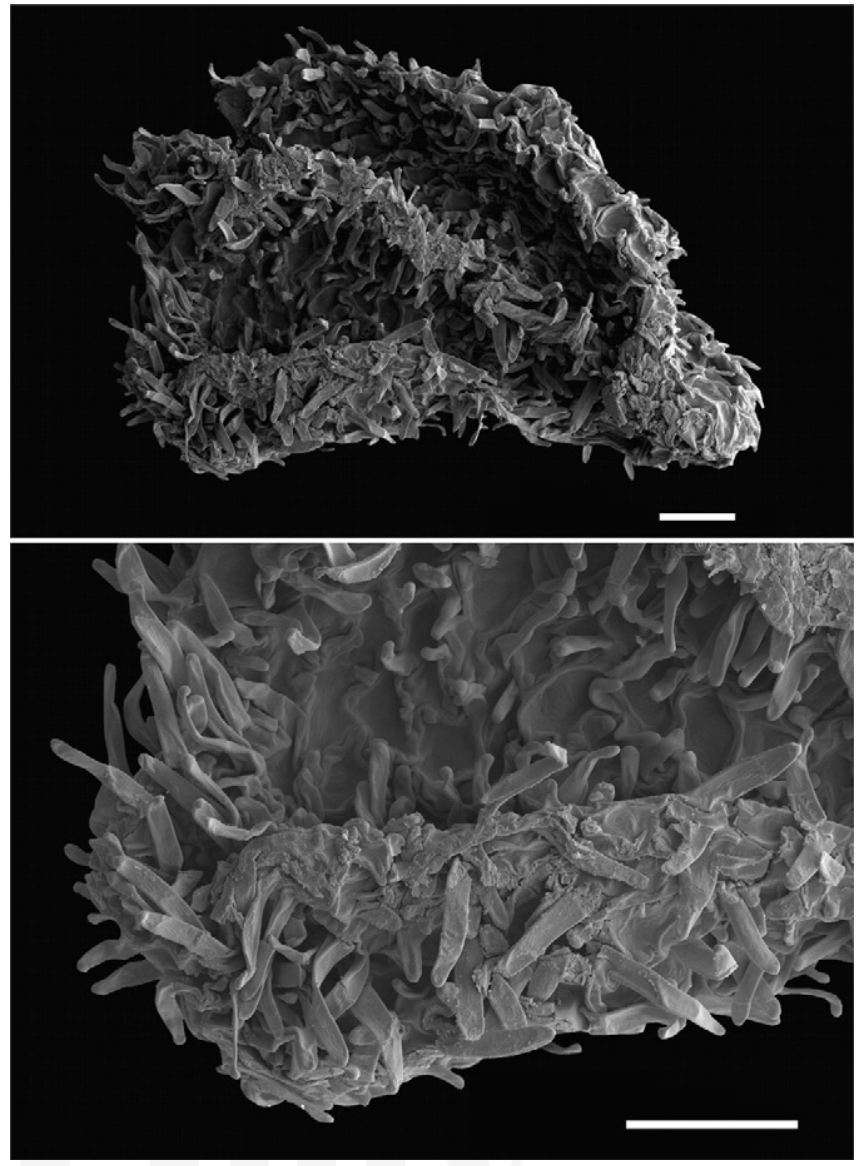

FIg. 3. SEM view of seed of Nicipe rosulata. Scale bars $100 \mu \mathrm{m}$. 
TABLE 2. A comparison of the main morphological characters of Nicipe rosulata, N. britteniae, and N. lithopsoides. Data obtained from wild and cultivated living plants and herbarium specimens. Percentiles 10 and 90 are indicated in parentheses.

\begin{tabular}{|c|c|c|c|}
\hline & N. rosulata & N. britteniae & N. lithopsoides \\
\hline Leaf number & $3-5(-8)$ & $(2-) 4-8$ & $10-18$ \\
\hline Leaf disposition & Spirally arranged rosette & Distichous rosette & Spirally arranged rosette \\
\hline Leaf length (mm) & $15-40(-70)$ & $25-50$ & $5-20$ \\
\hline Leaf width (mm) & $4-8(-10)$ & $8-11$ & $1-2$ \\
\hline $\begin{array}{c}\text { Synchrony of leafing } \\
\text { with flowering }\end{array}$ & Synanthous (in cult.) & Synanthous & Hysteranthous \\
\hline Leaf texture & Slightly leathery & Hard & Leathery \\
\hline Leaf shape & Flat and wide & Ensiform & Subterete \\
\hline Leaf folding & Widely canaliculate & Conduplicate & $\begin{array}{c}\text { Slightly canaliculate in } \\
\text { the adaxial side }\end{array}$ \\
\hline Margin indumentum & Fimbriate with cilia $0.3-0.5 \mathrm{~mm}$ long & $\begin{array}{l}\text { Densely fimbriate with cilia } \\
\text { ca. } 0.8 \mathrm{~mm} \text { long }\end{array}$ & $\begin{array}{l}\text { Minutely ciliolate with cilia } \\
0.1-0.2 \mathrm{~mm} \text { long }\end{array}$ \\
\hline Capsule & $\begin{array}{l}\text { Narrowly ovate-lanceolate, } \\
\text { acute, apiculate }\end{array}$ & Ovate, subobtuse & Ovate, subobtuse \\
\hline Seeds & Long papillate-echinulate & Rugose & Rugose \\
\hline
\end{tabular}

Habitat-The species grows in open karroid vegetation among rocks and pebbles (Fig. 2). The two known populations of Nicipe rosulata occur in the Succulent Karoo Biome, Rainshadow Valley Karoo Bioregion, and Eastern Little Karoo (SKv11) vegetation unit sensu Mucina and Rutherford (2006). This region shows aseasonal rainfall, with a mean of annual rainfall of $290 \mathrm{~mm}$, with slight optimum in March and a pronounced drought in December-January (Austral summer). Mean annual temperature is about $17^{\circ} \mathrm{C}$ and frost occurs only about nine days per year (cf. Mucina and Rutherford 2006).

Distribution-This species is only known from two localities, over $22 \mathrm{~km}$ apart in the Little Karoo in the Western Cape Province of South Africa: one south of Calitzdorp in the Gamkaberg Nature Reserve and the F4 other about $30 \mathrm{~km}$ west of Oudtshoorn (Fig. 4).

Taxonomic Relationships-Nicipe rosulata is easily identified by its (3-)5-8 short and broad somewhat leathery leaves disposed in a basal rosette, the capsule narrowly ovate, acuteapiculate and the seeds long papillate-echinulate (Figs. 1-3).

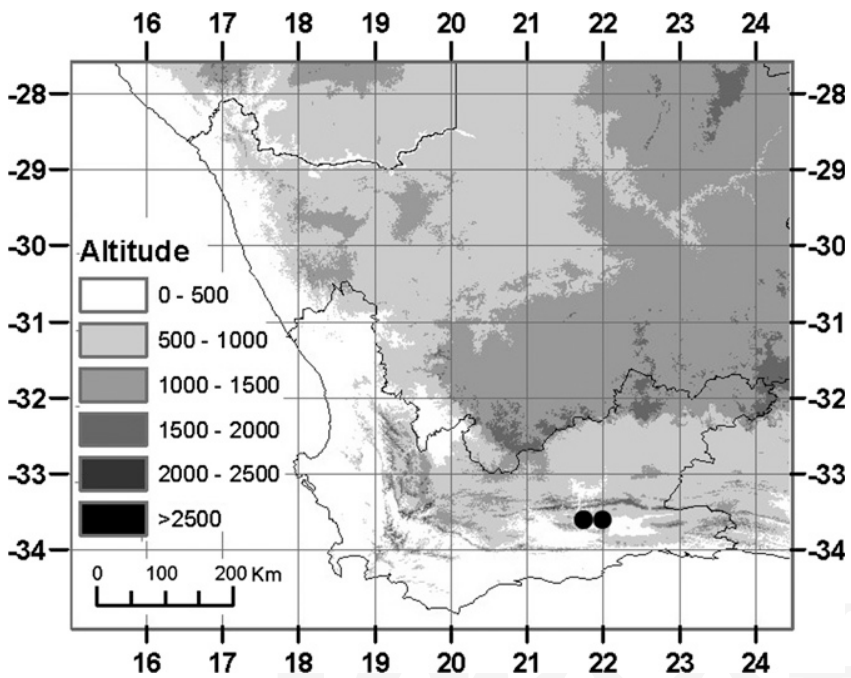

FIg. 4. Known distribution of Nicipe rosulata in South Africa. Axes show longitude $(S)$ and latitude $(E)$ in degrees.

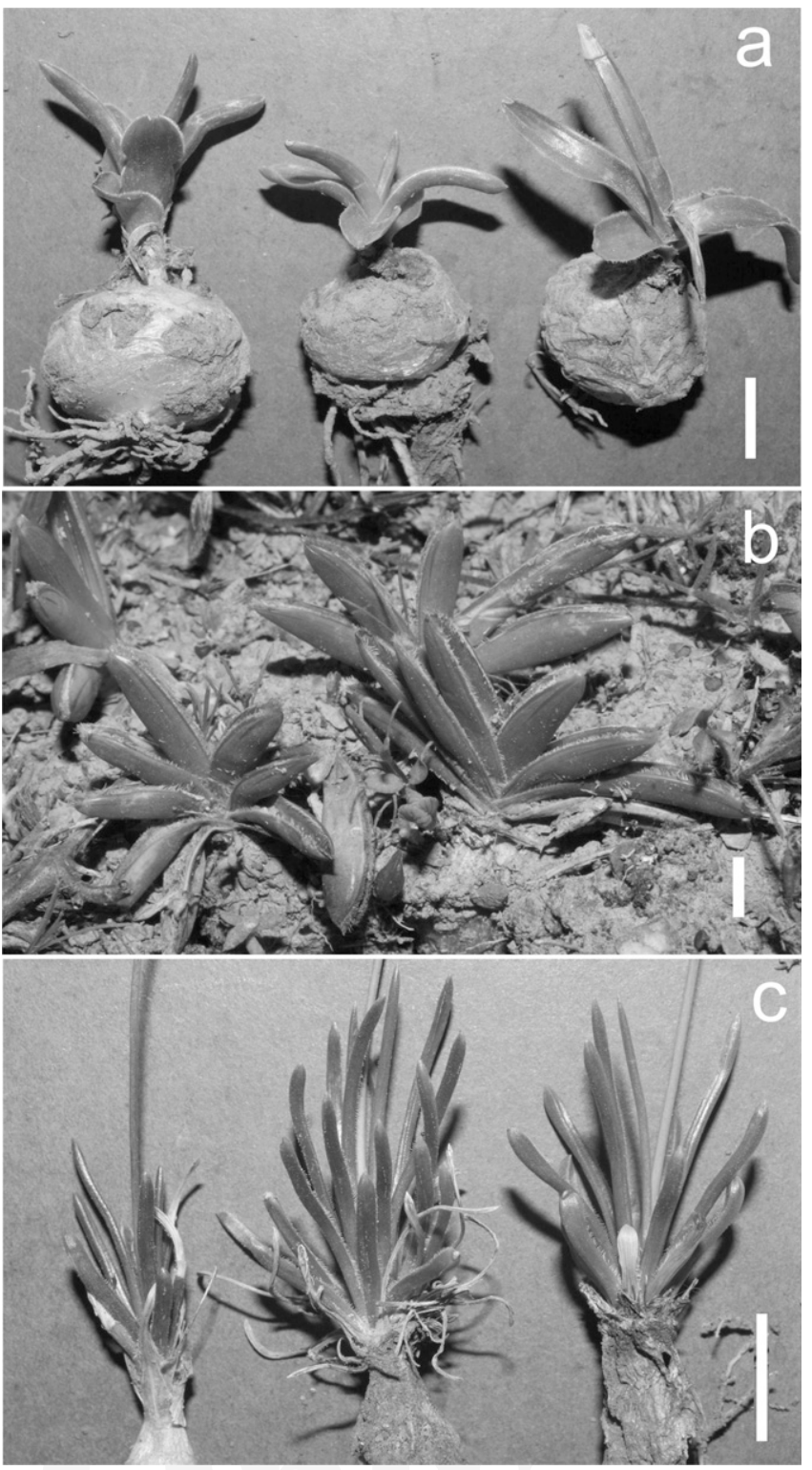

FIG. 5. Comparison of leaves of Nicipe rosulata (a), N. britteniae (b) and $N$. lithopsoides (c). Scale bars $1 \mathrm{~cm}$. 


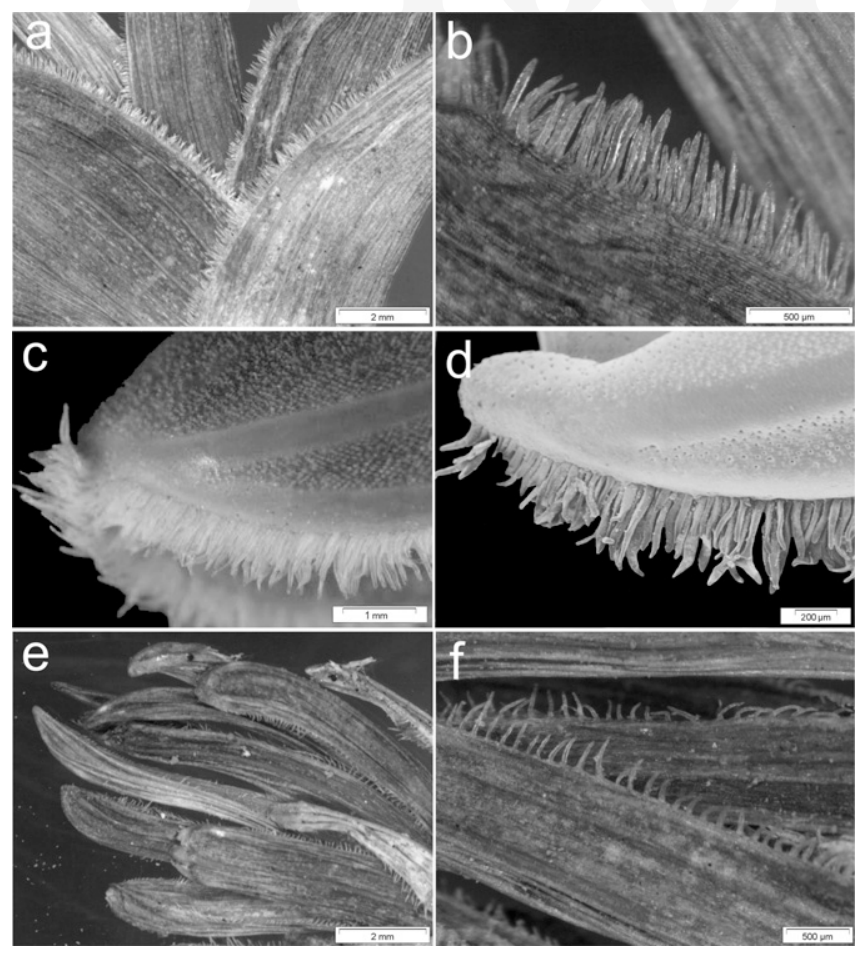

FIG. 6. Comparison of leaf indumentum in Nicipe rosulata (a-b), N. britteniae $(\mathrm{c}-\mathrm{d})$, and $N$. lithopsoides $(\mathrm{e}-\mathrm{f})$.

Nicipe rosulata appears at first sight morphologically similar to N. britteniae (F. M. Leight. ex Oberm.) Mart.-Azorín, M. B. Crespo \& Juan and Ornithogalum lithopsoides van Jaarsv. based on their short leaves, an unusual character in the genus. Diagnostically, Nicipe rosulata shares with $N$. britteniae the short and wide leaves, but the latter differs from $N$. rosulata by the hard, distichous, ensiform, conduplicate leaves, and the rugose seeds (cf. Obermeyer 1978; Dold

F5, F6 2003, 2005) (Table 2, Figs. 5-6). Regarding O. lithopsoides, it clearly differs from $N$. rosulata by the more numerous and much thinner leaves and the rugose seeds, among other characters (cf. Van Jaarsveld 2009) (Table 2, Figs. 5-6).

Three additional species of Nicipe with short and numerous leaves were described from the Little Karoo in recent years, but they can be easily differentiated from $N$. rosulata by clear characters. Nicipe adseptentrionesvergentula (U. Müll.-Doblies \& D. Müll.-Doblies) Mart.-Azorín, M. B. Crespo \& Juan differs from $N$. rosulata by the 7-17 subterete leaves, all bent towards north in the field, with patent, soft, somewhat crisp hairs $0.3-2 \mathrm{~mm}$ long along the margins and the abaxial side (cf. Müller-Doblies and Müller-Doblies 1996). A similar species to the latter one is Nicipe comptonii (F. M. Leight.) Mart.-Azorín, M. B. Crespo \& Juan, but it shows semiterete leaves with retrorse, setose hairs. Nicipe sardienii (van Jaarsv.) Mart.-Azorín, M. B. Crespo \& Juan is unique in the genus by having the ovary tuberculate at the apex, and 20-50 narrow leaves with six dorsal rows of cilia.

Most species in Nicipe have long, narrow leaves, much longer than wide; however, it is remarkable that at least eight species of Nicipe occur in the Little Karoo, and most of these have short leaves and mostly epigeal bulbs. It appears that the dry environmental conditions in that area, and perhaps herbivory, were strong selection pressures for the evolution of short stature to give protection among the rocks and pebbles common in the habitat (Fig. 2). The long papillate-echinulate seeds of Nicipe rosulata (Fig. 3) are rare in the genus and apparently only shared with $N$. pilosa (L. f.) Mart.-Azorín, M. B. Crespo \& Juan, but the latter differs by having the bulbs covered with hard, black shiny tunics, among other characters (cf. Obermeyer 1978; MüllerDoblies and Müller-Doblies 1996).

Conservation Status-From our known records, the new species is a narrow endemic to the Little Karoo region in the Western Cape Province. In both localities, subpopulations were not large, with fewer than 100 individuals seen.

Additional Specimen Examined (Paratype)—SOUTH AFRICA. Western Cape, ca. $11 \mathrm{~km}$ SW of Calitzdorp, Gamkaberg Nature Reserve (former Groenefontein Nature Reserve), near top of pass, sandy soil in rocky slopes, and rock pockets, $408 \mathrm{~m}, 29 / 09 / 2011$ (bulbs with leaves from wild plants), flowers ex hort. (28/01/2012 in Grahamstown), M. MartínezAzorin et al. MMA941 (ABH, GRA).

A New Combination in Nicipe-Ornithogalum lithopsoides was recently described by Van Jaarsveld (2009). This species shows the typical characters of the genus Nicipe, as described earlier. Consequently, a new combination in that genus is required to accommodate it, as shown below:

Nicipe lithopsoides (van Jaarsv.) Mart.-Azorín, M. B. Crespo, A. P. Dold, M. Pinter \& Wetschnig comb. nov. Ornithogalum lithopsoides van Jaarsv. in Aloe 46: 20. 2009 [basion.].

ACKNOWLedgments. This work was partly supported by the Fundación Ramón Areces (Spain) and Universidad de Alicante (Spain). Rhodes University provided working facilities from October 2009 to November 2011. We thank Tom Barry, manager of Gamkaberg Nature Reserve, for facilitating collecting of specimens. Curators of the herbaria kindly provided access to specimens examined. CapeNature of Western Cape Province provided permission to collect specimens (collecting permit number AAA008-00031-0028). Sincere thanks also go to Jan Vlok and Almudena Martínez-Soler who kindly assisted with field work. Technicians from the Microscopy Unit (SSTTI) of University of Alicante helped with SEM observations. Susan Abraham is also thanked for preparing the line drawing of the new species.

\section{Literature Cited}

APG II. 2003. An update of the Angiosperm Phylogeny Group classification for the orders and families of flowering plants: APG II. Botanical Journal of the Linnean Society 141: 399-436.

APG III. 2009. An update of the Angiosperm Phylogeny Group Classification for the orders and families of flowering plants: APG III. Botanical Journal of the Linnean Society 161: 105-121.

Chase, M. W., J. L. Reveal, and M. F. Fay. 2009. A subfamilial classification for the expanded asparagalean families, Amaryllidaceae, Asparagaceae and Xanthorrhoeaceae. Botanical Journal of the Linnean Society 161: 132-136.

Dold, A. P. 2003. The rediscovery of Ornithogalum britteniae (Hyacinthaceae) and an amendment to the description. South African Journal of Botany 69: 500-504.

Dold, A. P. 2005. The rediscovery of Ornithogalum britteniae. Mysteriously lost since 1946, an unusual South African bulb is re-found, properly described and finally propagated. Cactus and Succulent Journal 77: 2-5.

IPNI. 2014. The international plant names index. Available from: http:// www.ipni.org (accessed: January 2014).

Martínez-Azorín, M., M. B. Crespo, and A. Juan. 2007. Taxonomic revision of Ornithogalum subg. Cathissa (Salisb.) Baker (Hyacinthaceae). Anales del Jardin Botanico de Madrid 64: 7-25.

Martínez-Azorín, M., M. B. Crespo, and A. Juan. 2009. Taxonomic revision of Ornithogalum subg. Beryllis (Hyacinthaceae) in the Iberian Peninsula and the Balearic Islands. Belgian Journal of Botany 142: 140-162.

Martínez-Azorín, M., M. B. Crespo, A. Juan, and M. F. Fay. 2011. Molecular phylogenetics of subfamily Ornithogaloideae (Hyacinthaceae) based on nuclear and plastid DNA regions, including a new taxonomic arrangement. Annals of Botany (Oxford) 107: 1-37. 
Mucina, L. and M. C. Rutherford (eds.). 2006. The vegetation of South Africa, Lesotho and Swaziland. Strelitzia 19. Pretoria: South African National Biodiversity Institute.

Müller-Doblies, U. and D. Müller-Doblies. 1996. Revisionula incompleta Ornithogalorum Austro-Africanorum (Hyacinthaceae). Feddes Repertorium 107: 361-548.

Obermeyer, A. A. 1978. Ornithogalum: A revision of the southern African species. Bothalia 12: 323-376.
Rafinesque, C. S. 1837. Flora Telluriana 2. Philadelphia: H. Probasco.

Thiers, B. 2014. Index herbariorum: A global directory of public herbaria and associated staff. New York Botanical Garden's Virtual Herbarium. Available from: http://sweetgum.nybg.org/ih/ (accessed: January 2014).

Van Jaarsveld, E. J. 2009. A new succulent Ornithogalum species (Hyacinthaceae) from semi-arid regions in the southern Western Cape. Aloe 46: 20-21. 